\title{
Development of a new duplex real-time polymerase chain reaction assay for hepatitis $B$ viral DNA detection
}

\author{
Shipeng Sun ${ }^{1,2+}$, Shuang Meng ${ }^{3+}$, Rui Zhang ${ }^{1,2}$, Kuo Zhang ${ }^{1,2}$, Lunan Wang ${ }^{1,2}$ and Jinming Li $^{1,2^{*}}$
}

\begin{abstract}
Background: Quantification of hepatitis B virus (HBV) DNA can be used for diagnosing HBV infection and monitoring the effect of antiviral therapy. However, probably because of mismatches between the template and primer/probe, HBV DNA in some HBV infections could not be detected using currently available commercial assays with single primer/probe. By aligning the HBV sequences, we developed a duplex real-time polymerase chain reaction (PCR) assay using two sets of primers/probes and a specific armored DNA as internal control (IC).

Results: The limit of the duplex real-time PCR assay was $29.5 \mathrm{IJ} / \mathrm{ml}$, whereas the specificity was $100 \%$. The within-run precision coefficient of variation (CV) ranged from $1.02 \%$ to $2.73 \%$, while the between-run CV ranged from $0.83 \%$ to $1.25 \%$. The optimal concentration of armored DNA IC in the HBV DNA duplex real-time PCR assay was 1000 copies/ml. Data from 69 serum samples with HBV infection showed that the performance of the duplex real-time PCR assay was comparable to that of the COBAS Ampliprep/Cobas Taqman (CAP/CTM) HBV assay and was superior to those of the domestic commercial HBV assays.
\end{abstract}

Conclusions: The duplex real-time PCR assay is sufficiently sensitive, specific, accurate, reproducible and costeffective for the detection of HBV DNA. It is suitable for high throughput screening and frequent HBV DNA level monitoring.

\section{Background}

An estimated 600,000 persons worldwide die each year due to the acute or chronic consequences of hepatitis $B$ caused by the hepatitis B virus (HBV) infection [1]. Nowadays, HBV infection is a leading cause of death in China [2]. Of the 350-400 millions people with chronic hepatitis B, a third of them live in China [3]. Serologic tests were used routinely for the diagnosis of HBV infection. However, during the window period of hepatitis B virus infection, early diagnosis and follow-up of infection cannot be achieved by serologic tests. Moreover, some studies indicate that HBV may be transmitted by individuals with occult $\mathrm{HBV}$ infection (OHB), that is, persons who have no serologic evidences of ongoing HBV replication $[4,5]$.

\footnotetext{
* Correspondence: ljm63hn@yahoo.com.cn

+ Contributed equally

'National Center for Clinical Laboratories, Beijing Hospital, Beijing, People's Republic of China

Full list of author information is available at the end of the article
}

The best indication of active viral replication is detection of HBV DNA in plasma or serum [6-9]. Several assays based on real-time PCR have been developed for quantification of HBV DNA in serum or plasma samples [10-12]. Compared to serologic tests, real-time PCRbased assays with high sensitivity and high specificity may allow earlier diagnosis of HBV infection $[13,14]$. HBV polymerase lacks proofreading activity, thus, the mutation rate for HBV is higher than the rate observed for most DNA viruses $[15,16]$. Currently there are eight accepted genotypes (A to $\mathrm{H}$ ) for HBV based on the inter-group divergence of $8 \%$ or more in the complete genome sequence [17]. High mutation rate of viral genomes may results in failure to recognize increasing viremia levels [18] and even miss detecting HBV DNA by real-time PCR assay with single primer/probe because of mismatches between the template and the primer/probe $[19,20]$. Previous studies indicated that the performances of duplex real-time reverse transcriptase-PCR assay have been improved and could avoid missing detection of
C Biomed Central

() 2011 Sun et al; licensee BioMed Central Ltd. This is an Open Access article distributed under the terms of the Creative Commons Attribution License (http://creativecommons.org/licenses/by/2.0), which permits unrestricted use, distribution, and reproduction in any medium, provided the original work is properly cited. 
hepatitis $\mathrm{C}$ virus $(\mathrm{HCV})$ and Human immunodeficiency virus (HIV) to some extent with two sets of primer/probe $[21,22]$. Similarly, a real-time PCR assay with two sets of primer/probe may resolve the problem of mismatches and avoid missing detections of HBV infection. However, rare information has been published on the duplex realtime PCR assay for HBV DNA quantification.

In addition, it is necessary to use an internal control (IC) to monitor the specimen extraction and amplification efficiency of real-time PCR assay. Compared with commonly used plasmid IC, armored DNA produced by the lambda phage system is DNase-resistant, stable, noninfectious, inexpensive, and easily to be extracted and could be used as an ideal control for clinical viral testing [23-25].

In this study we developed a duplex real-time PCR assay with armored DNA as IC for HBV DNA detection. The assay possesses all the performance characteristics that make it amenable for high throughput screening of HBV infection.

\section{Materials and methods}

\section{Serum samples and standards}

$30 \mathrm{HBV}$-positive and $10 \mathrm{HBV}$-negative samples from Beijing Blood Center (Beijing, China) were used for comparison of the performances of singleplex primer/ probe and duplex primer/probe assays.

$100 \mathrm{HBV}$-negative blood donors serum samples including 80 healthy controls and 20 controls with hepatitis $\mathrm{A}$, hepatitis $\mathrm{C}$, hepatitis $\mathrm{E}$, human immunodeficiency virus type 1 infection, or human T-cell leukaemia virus infection (confirmed at the blood bank) were enrolled.

Furthermore, 69 serum samples were collected from Shenzhen Blood Center (Guangdong, China). Each sample was divided into 4 aliquots and frozen at $-80^{\circ} \mathrm{C}$ within $4 \mathrm{~h}$ after collection. These samples were used to compare the performances of Kehua HBV DNA real-time PCR detection kit (Shanghai Kehua Bio-Engineering Co. Ltd., Shanghai, China), qualitative duplex real-time PCR assay, and COBAS Ampliprep/Cobas Taqman (CAP/CTM) assay (Roche Molecular Systems, Pleasanton, CA).

A dilution series of the World Health Organization (WHO) Second International Standard for HBV DNA (National Institute for Biological Standards and Control (NIBSC), code $97 / 750$, UK) was used to determine the limit of detection (LOD) of the duplex real-time PCR assay at the following concentrations: $5,10,25,50,10^{2}, 10^{3}, 10^{4}$ and $10^{5} \mathrm{IU} / \mathrm{ml}$. Each dilution of the WHO Standard was tested in a batch of 4 replicates in 6 separate runs, i.e. for each dilution, a total of 24 replicates were tested.

\section{Selection of duplex real-time PCR primers and probes}

In order to identify optimal sites for primers design, 44 HBV complete genome reference sequences representative of all eight genotypes (A-H) downloaded from GenBank Database were aligned using DNA star software. GeneBank accession numbers of 44 HBV complete genome reference sequences are genotypes A (AB194951, AF090842, AJ309369, AY217375, U87742, X02763, X51970); genotypes B (AB010292, AB031266, AB033554, AB033555, AF100309, D00329, U87747); genotypes C (AB014381, AB048704, AB049609, AB241110, AY123041, X01587, X04615, X75665); genotypes D (AY090453, M32138, V01460, X65259, X85254); genotypes E (AB032431, DQ060823, X75657); genotypes F (AB036905, AB036910, AB086397, AF223962, AF223965, AY090455, X69798); genotypes G (AB064310, AF160501, AF405706); genotypes G (AB059661, AY090454, AY090457, AY090460). Based on the consensus sequences of the HBV genome, two sets of primer/probe (A and B) targeting $S$ genes and probe for IC (ICp) were designed (Table 1). To ensure the primers only amplify HBV DNA, they were tested by the BLAST algorithm.

\section{Construction and selection of optimal concentration of IC} Armored DNA was produced with the same method as described [23]. The sequences of IC were identical to the wild-type HBV sequences, except for the sequences of probe Ap- and probe Bp-binding site, which were replaced by the internal probe sequences (5' CCCCCCCCCCCCCCAAAAAAAA 3'). A chequerboard assay was performed in which the international reference material for HBV DNA (NIBSC 97/746; $0 \mathrm{IU} / \mathrm{ml}, 5 \times 10^{2}$ $\left.\mathrm{IU} / \mathrm{ml}, 5 \times 10^{3} \mathrm{IU} / \mathrm{ml}, 5 \times 10^{4} \mathrm{IU} / \mathrm{ml}, 5 \times 10^{5} \mathrm{IU} / \mathrm{ml}\right)$ were spiked with four different copy numbers $\left(10^{5}, 10^{4}\right.$, $\left.10^{3}, 0\right)$ of the armored DNA. Armored DNA was extracted and amplified with the international reference material for HBV DNA in the same reaction tube.

\section{Duplex real-time PCR and singleplex real-time PCR amplification for HBV DNA detection}

DNA was extracted from $100 \mu \mathrm{l}$ sample by using extraction reagents of the Kehua HBV DNA real-time PCR detection kit according to the manufacturer's instructions. $1.0 \mu \mathrm{l}$ armored DNA particles (1000 copies/ $\mu \mathrm{l})$, added to each sample prior to extraction, were used as ICs of the extraction and amplification processes. The final optimized PCR mixture $(25 \mu \mathrm{l})$ contained $12.5 \mu \mathrm{l}$ QuantiTect Probe PCR Master Mix (QIAGEN, QuantiTect Multiplex PCR kit), $1.0 \mu \mathrm{l}$ armored DNA particles, $8 \mu \mathrm{l} \mathrm{HBV}$ DNA samples and the concentration of primer/probe were added as follows, in the singleplex mode, either the primer/probe set A $(0.4 \mu \mathrm{M}$ primers, $0.4 \mu \mathrm{M}$ probes, and $0.2 \mu \mathrm{M}$ IC-specific probe) or the primer/probe set $\mathrm{B}(0.4 \mu \mathrm{M}$ primers, $0.4 \mu \mathrm{M}$ probes, and $0.2 \mu \mathrm{M}$ IC-specific probe), was used in the reaction, whereas in the duplex mode, both the primer/probe sets $\mathrm{A}(0.4 \mu \mathrm{M}$ primers, $0.4 \mu \mathrm{M}$ probes, and $0.2 \mu \mathrm{M}$ 


\begin{tabular}{lll}
\hline Primer or probe & Sequence $\mathbf{( 5}^{\prime}$-3') & Nucleotide Position \\
\hline Af & 5'- GTCCTCCAATTGTCCTGG -3' & $2196-2214$ \\
Ar & 5'- TGAGGCATAGCAGCAGGAT -3' & $2276-2258$ \\
Ap & 5' FAM - CTGGATGTGTCTGCGGCGTTTATCAT - BHQ 3' & $2221-2247$ \\
Bf & 5'- CACCTGTATCCCATCCCATC -3' & $2443-2458$ \\
Br & 5'- AGCCCTACGAACCACTGAACA -3' & $2559-2539$ \\
Bp & 5' FAM - AAACGGACTGAGGCCCACTCCCA -BHQ 3' & $2511-2489$ \\
ICp & 5' Cy5 - CCCCCCCCCCCCCCAAAAAAAA -BHQ 3' \\
\hline
\end{tabular}

Nucleotide sequence positions were numbered according to reference sequence AF090842 (genotype A). Probes for the detection of HBV DNA and IC were labelled with 6-carboxyfluorescein (FAM) and cyanine dye (Cy5) at the $5^{\prime}$ end, respectively. The $3^{\prime}$ ends of probes were labelled with Black Hole Quencher dye (BHQ). The length of PCR products amplified from set A and B are $81 \mathrm{bp}$ and $117 \mathrm{bp}$, respectively.

IC-specific probe) and B $(0.4 \mu \mathrm{M}$ primers, $0.4 \mu \mathrm{M}$ probes, and $0.2 \mu \mathrm{M}$ IC-specific probe) were used in PCR $(0.4 \mu \mathrm{M}$ primers, $0.4 \mu \mathrm{M}$ probes, and $0.2 \mu \mathrm{M}$ IC-specific probe). PCR was performed with an ABI 7500 sequence detection system as follows: an initial denaturation step at $95^{\circ} \mathrm{C}$ for $15 \mathrm{~min}, 45$ cycles at $94^{\circ} \mathrm{C}$ for $15 \mathrm{~s}$ and $60^{\circ} \mathrm{C}$ for $1 \mathrm{~min}$.

\section{Evaluation of the duplex real-time PCR assay}

To establish the linearity of HBV DNA quantification, we prepared serial 10-fold dilutions from the HBV standard in negative serum to obtain concentrations of 10 , $10^{2}, 10^{3}, 10^{4}, 10^{5}$, and $10^{6} \mathrm{IU} / \mathrm{ml}$. Each concentration was tested three replicates in a single run.

A set of $3 \mathrm{HBV}$ positive serum samples with different viral loads was tested 10 times in a single run to determine within-run precision coefficient of variation $(\mathrm{CV})$ in the viral quantification. Similarly, the same set of samples was quantified in 10 different experiments to determine between-run $\mathrm{CV}$ in the viral quantification. The coefficients of variance (CV) of the threshold cycles (Ct) were calculated.

\section{Commercial kits for HBV DNA detection}

A total of 69 serum samples were tested using Kehua HBV DNA real-time PCR detection kit and CAP/CTM assay kit. All the operation steps were carried out according to the instructions given in the manuals.

(i) Detection using Kehua HBV DNA real-time PCR detection kit. HBV DNA was extracted from $100 \mu \mathrm{l}$ sample, and $12.5 \mu \mathrm{l}$ extract was used as the template in $25 \mu \mathrm{l}$ reaction. PCR was carried out in a 32-well Lightcycler thermal cycles system (Roche). HBV DNA levels were expressed in $\mathrm{IU} / \mathrm{ml}$. The LOD of Kehua HBV DNA assay kit was $500 \mathrm{IU} / \mathrm{ml}$.

(ii) Detection using CAP/CTM HBV assay kit. The CAP/CTM test utilized automated specimen preparation on the COBAS AmpliPrep Instrument by a generic silica-based capture technique. HBV DNA was extracted from $850 \mu \mathrm{l}$ serum and then eluted with $65 \mu \mathrm{l}$ of elution buffer. Finally, $50 \mu \mathrm{l}$ extract was used as the template in $100 \mu \mathrm{l}$ reaction volume. The COBAS TaqMan 48
Analyzer was used for automated real-time PCR amplification. HBV DNA levels were expressed in $\mathrm{IU} / \mathrm{ml}$. The LOD of CAP/CTM HBV assay kit was $12 \mathrm{IU} / \mathrm{ml}$.

Comparison the duplex primer/probe real-time PCR assays with the singleplex primer/probe real-time PCR assays for HBV DNA detection

The results of $30 \mathrm{HBV}$-positive and $10 \mathrm{HBV}$-negative samples tested by singleplex primer/probe and duplex primer/probe assays were compared.

\section{Comparison the duplex primer/probe real-time PCR assay} with commercial kits for HBV DNA detection

69 serum samples were tested by Kehua HBV DNA real-time PCR detection kit, qualitative duplex real-time PCR assay, and COBAS CAP/CTM assay, the results were then compared.

\section{Data analysis}

Results were expressed as means and standard deviation (SD). The intra-assay and inter-assay variations were expressed as coefficient of variation (CV), based on the mean $\mathrm{Ct}$ values. Probit analysis was performed to determine the LOD. The LOD was determined as $95 \%$ probability of obtaining a positive HBV DNA result. Correlation coefficients $(\mathrm{R})$ were calculated for linearity data.

\section{Results}

Optimal concentration of IC

To establish the optimum copy number of internal control to be added to the tubes for HBV DNA duplex real-time PCR assay, a chequerboard assay was performed in which serially diluted HBV standards $\left(5 \times 10^{5}\right.$ to $\left.0 \mathrm{IU} / \mathrm{ml}\right)$ were spiked with four different copy numbers $\left(10^{5}\right.$ to 0$)$ of the internal control armored DNA (Table 2). The IC copies more than 1000 changed the threshold cycles $(\mathrm{Ct})$ for almost all the standards which resulted in the underestimation of the copy number. The optimal concentration of armored DNA IC in the HBV DNA duplex real-time PCR assay was 1000 copies/ml. 
Table 2 Optimization of the concentration of IC

\begin{tabular}{|c|c|c|c|c|c|c|c|c|c|}
\hline \multirow[t]{2}{*}{$\begin{array}{l}\text { Armored DNA concentration } \\
\text { (copies } / \mathrm{ml})\end{array}$} & \multicolumn{2}{|c|}{$\begin{array}{l}\text { National reference } \\
\text { material } 4 \text { for HBV } \\
\text { DNA } 5 \times 10^{5} \mathrm{IU} / \mathrm{ml}\end{array}$} & \multicolumn{2}{|c|}{$\begin{array}{l}\text { National reference } \\
\text { material } 3 \text { for HBV } \\
\text { DNA } 5 \times 10^{4} \mathrm{IU} / \mathrm{ml}\end{array}$} & \multicolumn{2}{|c|}{$\begin{array}{l}\text { National reference } \\
\text { material } 2 \text { for HBV } \\
\text { DNA } 5 \times 10^{3} \mathrm{IU} / \mathrm{ml}\end{array}$} & \multicolumn{2}{|c|}{$\begin{array}{l}\text { National reference } \\
\text { material } 1 \text { for HBV } \\
\text { DNA } 5 \times 10^{2} \mathrm{IU} / \mathrm{ml}\end{array}$} & \multirow{2}{*}{$\begin{array}{c}\mathrm{HBV} 0 \mathrm{lU} / \\
\mathrm{ml}\end{array}$} \\
\hline & $\begin{array}{c}\text { IC (Cy5) } \\
\mathrm{Ct}\end{array}$ & $\begin{array}{c}\text { HBV (FAM) } \\
\text { Ct }\end{array}$ & $\begin{array}{c}\text { IC (Cy5) } \\
\text { Ct }\end{array}$ & $\begin{array}{c}\text { HBV (FAM) } \\
\text { Ct }\end{array}$ & $\begin{array}{c}\text { IC (Cy5) } \\
\text { Ct }\end{array}$ & $\begin{array}{l}\text { HBV (FAM) } \\
\text { Ct }\end{array}$ & $\begin{array}{c}\text { IC (Cy5) } \\
\text { Ct }\end{array}$ & $\begin{array}{l}\text { HBV (FAM) } \\
\text { Ct }\end{array}$ & \\
\hline 100000 & 38.92 & 28.00 & 34.43 & 32.17 & 31.18 & 35.78 & 30.33 & $>45$ & 30.13 \\
\hline 10000 & 41.51 & 28.93 & 38.39 & 31.20 & 35.58 & 34.29 & 34.29 & 39.55 & 34.21 \\
\hline 1000 & $>45$ & 23.14 & 38.35 & 26.44 & 37.72 & 29.23 & 35.68 & 32.67 & 35.47 \\
\hline 0 & $>45$ & 23.21 & $>45$ & 26.11 & $>45$ & 29.14 & $>45$ & 32.82 & $>45$ \\
\hline
\end{tabular}

Concentrations of HBV DNA and armored DNA were indicated by FAM and Cy5 signals, respectively.

\section{Evaluation of the duplex real-time PCR assay}

Linearity of the duplex real-time PCR assay was determined using serial 10-fold dilutions of HBV standard in negative serum samples at the following concentrations: $10,10^{2}, 10^{3}, 10^{4}, 10^{5}$, and $10^{6} \mathrm{IU} / \mathrm{ml}$. Three replicates were tested in a single run at each concentration. The proportion of positive results obtained from each input concentration was subjected to probit regression analysis (Table $3)$. The LOD of the duplex real-time PCR assay was 29.5 $\mathrm{IU} / \mathrm{ml}$ (95\% confidence interval, 20.9-56.2 IU/ml). Linear regression analysis of the $\mathrm{Ct}$ values against the log10 HBV DNA concentration yielded $\mathrm{R}=0.993$ (Figure 1 ). The specificity of the duplex real-time PCR assay was $100 \%$ when testing HBV-negative serum samples.

The intra-assay variation was assessed by testing 3 samples with different viral loads $\left(10^{5}, 10^{4}\right.$, and $\left.10^{2} \mathrm{IU} / \mathrm{ml}\right) 10$ times in a single run, while the inter-assay variation was assessed by testing the same samples 10 times in 10 separate runs. The intra-assay CV ranged from $0.83 \%$ to $1.25 \%$, while the inter-assay CV ranged from $1.02 \%$ to $2.73 \%$ (Table 4 ).

Comparison the duplex primer/probe real-time PCR assays with the singleplex primer/probe real-time PCR assays for HBV DNA detection

40 serum samples were submitted for routine HBV DNA testing. The duplex primer/probe assay could strengthen the fluorescence signal of the low HBV viraemia samples. Figure 2 showed the performance of the duplex primer/probe $(\mathrm{C})$ and singleplex primer/probe

Table 3 Limit of detection of the duplex real-time PCR assay

\begin{tabular}{ccc}
\hline HBV load (IU/ml) & Positive results/total tested & Positive results (\%) \\
\hline $10^{5}$ & $24 / 24$ & 100 \\
$10^{4}$ & $24 / 24$ & 100 \\
$10^{3}$ & $24 / 24$ & 100 \\
$10^{2}$ & $24 / 24$ & 100 \\
50 & $24 / 24$ & 100 \\
25 & $22 / 24$ & 91.6 \\
10 & $12 / 24$ & 50.0 \\
5 & $5 / 24$ & 20.8 \\
\hline
\end{tabular}

(A, B) assays in the testing the same low-load HBV sample. Of the confirmed $30 \mathrm{HBV}$ DNA positive samples, both singleplex primer/probe set A and set B failed to detect 2 low $\mathrm{HBV}$ viraemia samples. In contrast, the duplex primer/probe sets $\mathrm{A}+\mathrm{B}$ detected all the $30 \mathrm{HBV}$ positive serum samples (Table 5).

Comparison the duplex primer/probe real-time PCR assay with commercial kits for HBV DNA detection

A set of 69 serum samples were tested in duplicate to verify the validity of the duplex primer/probe real-time PCR assay. Results obtained by the duplex real-time PCR assay were comparable to those obtained by the CAP/CTM assay. Kehua HBV DNA real-time PCR assay kit failed to detect 10 samples, which could be detected by the duplex primer/probe real-time PCR assay and the CAP/CTM assay (Table 6).

\section{Discussion}

In this study, we developed a novel HBV DNA quantification system using a real-time PCR assay which

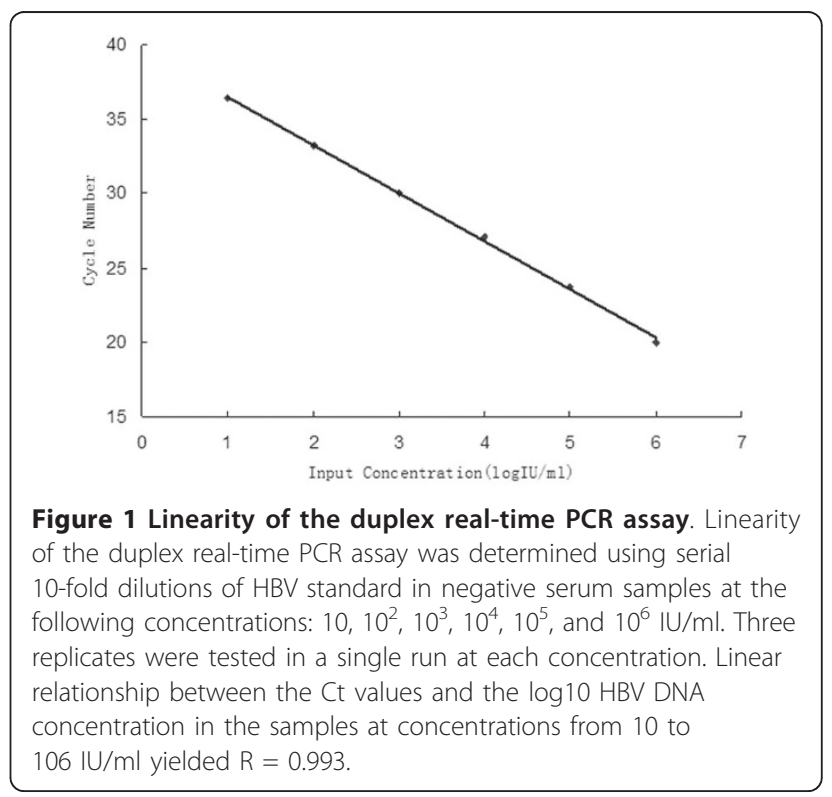


Table 4 Reproducibility of the duplex real-time PCR assay

\begin{tabular}{cccccc}
\hline Reproducibility & $\begin{array}{c}\text { Target HBV } \\
\text { RNA (IU/ml) }\end{array}$ & $\begin{array}{c}\text { Number of } \\
\text { determinations }\end{array}$ & $\begin{array}{c}\text { Mean } \\
\mathbf{C t}\end{array}$ & SD & $\begin{array}{c}\text { CV } \\
\mathbf{( \% )}\end{array}$ \\
\hline Intra-assay & $10^{5}$ & 10 & 24.15 & 0.24 & 0.83 \\
& $10^{4}$ & 10 & 27.09 & 0.34 & 1.07 \\
& $10^{2}$ & 10 & 33.31 & 0.49 & 1.25 \\
Inter-assay & $10^{5}$ & 10 & 24.05 & 0.27 & 1.02 \\
& $10^{4}$ & 10 & 27.05 & 0.23 & 0.77 \\
& $10^{2}$ & 10 & 33.23 & 1.02 & 2.73 \\
\hline
\end{tabular}

consisted of two sets of primer/probe and armored DNA as internal control in a single reaction tube. The primers and two FAM labelled probes were designed corresponding to the highly conserved HBV S gene. Compared with the singleplex primer/probe real-time PCR assay, the performance of duplex real-time PCR assay was remarkably improved and could avoid missing detection of HBV DNA to maximum extent with two sets of primer/probe.

The efficacy and accuracy of real-time PCR largely depend on the primers and probe [26]. It has been reported that several commercial HCV assays using a singleplex primer/probe set produce false-negative results because of mismatches between the template and primers/ probes $[27,28]$. Similarly, a single primer/probe may result in failure to recognize increasing viremia levels [18] and even miss detections because of mismatches for HBV DNA detection. Theoretically, the assay developed in this study can detect all eight genotypes of HBV with the two sets of primer/probe, especially the genotype A, B, C and G of HBV which genome DNA can be matched by both sets of primer/probe. Data from 69 serum samples from patients with HBV infection showed that the duplex primer/probe assay developed for HBV DNA detection can avoid mismatches between primer/probe and virus DNA template to maximum extent. Of the confirmed $30 \mathrm{HBV}$ DNA positive samples, two HBV-samples failed to detect by singleplex primer/probe set, but detected by duplex primer/probe set. The 2 sets of primers/probes used in our assay could match interchangeably, creating additional combinations with different primer-directed elongations. Figure 2 shows the performances of the duplex primer/ probe and singleplex primer/probe assays in the testing of the same serum sample. Obviously, the fluorescence value of the 2 sets of primers/probes is higher than that of the single set of primers/probes, and cycle threshold $(\mathrm{Ct})$ can shift towards left. As a result, the duplex primer/probe

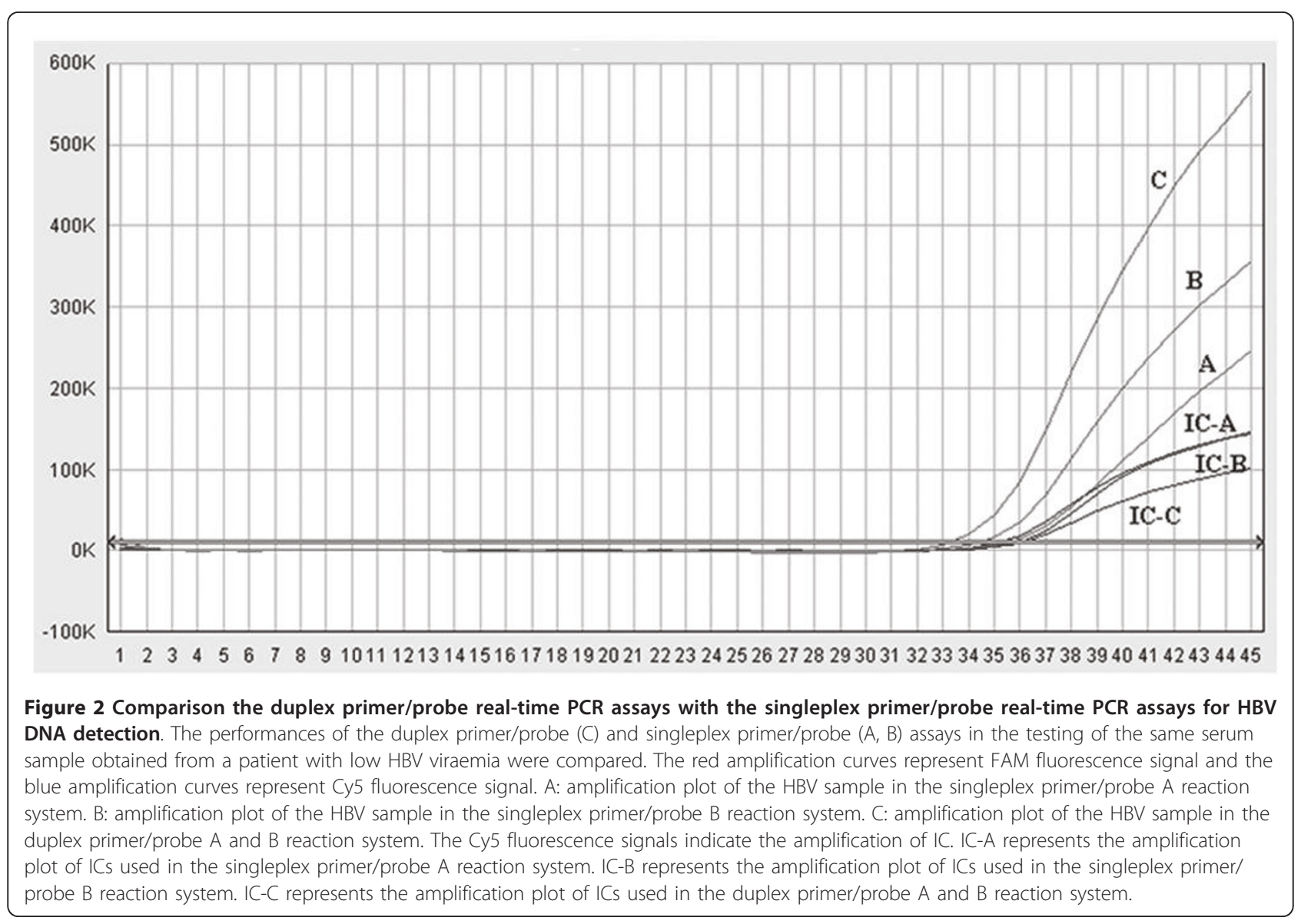


Table 5 Testing results of duplex real-time PCR assay and singleplex real-time PCR assay for $\mathbf{4 0}$ serum samples

\begin{tabular}{cccc}
\hline $\begin{array}{c}\text { Duplex } \\
\text { primer/ } \\
\text { probe } \\
\text { assay }\end{array}$ & $\begin{array}{c}\text { Singleplex primer/ } \\
\text { probe assay (set A } \\
\text { primer/probe) }\end{array}$ & $\begin{array}{c}\text { Singleplex primer/ } \\
\text { probe assay (set B } \\
\text { primer/probe) }\end{array}$ & $\begin{array}{c}\text { Number of } \\
\text { samples } \\
\text { detected }\end{array}$ \\
\hline+ & + & + & 28 \\
+ & - & - & 2 \\
- & - & - & 10 \\
\hline
\end{tabular}

+ : positive result.

$-:$ negative result.

assay could strengthen the fluorescence signal of the low HBV viraemia samples and increase the probability of detection (Figure 2). The manufacturer's lower LOD of the CAP/CTM assay and Kehua HBV fluorescence detection kit are $12 \mathrm{IU} / \mathrm{ml}$ and $500 \mathrm{IU} / \mathrm{ml}$, respectively. The sensitivity and the specificity of the duplex assay were comparable with the CAP/CTM assay and were superior to domestic Kehua HBV fluorescence detection kit. Furthermore, less serum samples $(100 \mu \mathrm{l}$ serum $)$ and lower cost were required than the CAP/CTM assay.

In order to identify PCR-inhibited samples, an armored DNA was constructed as IC in PCR assays by means of the overlapping extension PCR technique. Unlike the plasmid-derived control which can only monitor the amplification process, armored DNA was co-extracted and co-amplified with the samples in the same reaction tube that can monitor the entire real-time PCR assay [23]. IC sequences were identical to the wildtype HBV sequences, except that the probe binding site sequences were replaced by the internal probe ones. The 5' ends of probes for the detection of HBV were labelled with 6-carboxyfluorescein (FAM), while probe for the detection of IC was labelled with cyanine dye (Cy5), so that the amplification of the IC could be distinguished easily from that of the HBV virus by different fluorophore. In order to avoid its suppression to target amplification, the concentration of competitive IC (CIC) spiked into the samples was optimized at $1000 \mathrm{copies} / \mathrm{ml}$ in the real-time assay (Table 2). Although with HBV standards number at $5 \times 10^{5} \mathrm{IU} / \mathrm{ml}$, the amplification of the IC DNA (1000 copies/ml, Ct > 45) was competitively

Table 6 Testing results of different assays and kits for 69 serum samples

\begin{tabular}{cccc}
\hline $\begin{array}{c}\text { Kehua HBV DNA real- } \\
\text { time PCR detection kit }\end{array}$ & $\begin{array}{c}\text { CAP/CTM } \\
\text { HBV assay }\end{array}$ & $\begin{array}{c}\text { Duplex } \\
\text { primer/probe } \\
\text { assay }\end{array}$ & $\begin{array}{c}\text { Number of } \\
\text { samples } \\
\text { detected }\end{array}$ \\
\hline+ & + & + & 45 \\
- & + & + & 10 \\
- & - & - & 14 \\
\hline
\end{tabular}

+ : positive result.

-: negative result. inhibited. It does not affect the inclusion of an internal control to monitor for false negative results due to DNA degradation or to inhibitory factors potentially present in clinical samples. By using this armored DNA as IC, false negative samples that resulted from inappropriate reagent additions in the tubes or the presence of PCR inhibitors can be easily identified. Here, no inhibitors were found in the clinical samples tested in the duplex primer/probe assay.

\section{Conclusions}

We proved that two sets of primer/probe in the real-time PCR assay can effectively resolve the problem of mismatches and avoid missing detections of HBV infection. The established duplex real-time PCR assay is sufficiently sensitive, specific, accurate, reproducible and cost-effective for the detection of HBV DNA. It is suitable for high throughput screening and frequent HBV DNA level monitoring. Nevertheless, this study was carried out in China with a relatively small cohort, application of the duplex real-time PCR assay might be validated by larger serum samples including OHB serum samples.

\section{Acknowledgements}

This study was supported, in part, by the National Natural Science Foundation of China (30371365) and the National Key Technology R\&D Program (Grant 2007BA105B09) of China.

\section{Author details}

${ }^{1}$ National Center for Clinical Laboratories, Beijing Hospital, Beijing, People's Republic of China. ${ }^{2}$ Graduate School, Peking Union Medical College, Chinese Academy of Medical, Sciences, Beijing, People's Republic of China. ${ }^{3}$ State Key Laboratory for Infectious Disease Prevention and Control, National Institute for Communicable Disease Control and Prevention, Chinese Center for Disease Control and Prevention, Beijing, PR China.

\section{Authors' contributions}

SPS and SM performed the experiments, participated in the sequence alignment and analyzed the data and drafted the manuscript. RZ, KZ and LNW involved in analyzing the data and revising the manuscript. JML conceived and designed the experiments, contributed reagents/materials/ analysis tools. All authors read and approved the final manuscript.

\section{Competing interests}

The authors declare that they have no competing interests.

Received: 9 November 2010 Accepted: 14 May 2011

Published: 14 May 2011

References

1. Hepatitis B. [http://www.who.int/mediacentre/factsheets/fs204/en/].

2. Zou L, Zhang W, Ruan S: Modeling the transmission dynamics and control of hepatitis B virus in China. J Theor Biol 2010, 262:330-338.

3. Custer B, Sullivan SD, Hazlet TK, Iloeje U, Veenstra DL, Kowdley KV: Global epidemiology of hepatitis B virus. J Clin Gastroenterol 2004, 38 S158-168.

4. Ghisetti V, Marzano A, Zamboni F, Barbui A, Franchello A, Gaia S, Marchiaro G, Salizzoni M, Rizzetto M: Occult hepatitis B virus infection in $\mathrm{HBsAg}$ negative patients undergoing liver transplantation: clinical significance. Liver Transp/ 2004, 10:356-362.

5. Gupta S, Singh S: Occult hepatitis B virus infection in ART-naive HIVinfected patients seen at a tertiary care centre in north India. BMC Infect Dis 2010, 10:53. 
6. Dai CY, Yu ML, Chen SC, Lin ZY, Hsieh MY, Wang LY, Tsai JF, Chuang WL, Chang WY: Clinical evaluation of the COBAS Amplicor HBV monitor test for measuring serum HBV DNA and comparison with the Quantiplex branched DNA signal amplification assay in Taiwan. J Clin Pathol 2004, 57:141-145.

7. Zhang YY, Hansson BG, Kuo LS, Widell A, Nordenfelt E: Hepatitis B virus DNA in serum and liver is commonly found in Chinese patients with chronic liver disease despite the presence of antibodies to $\mathrm{HBsAg}$. Hepatology 1993, 17:538-544.

8. Heermann KH, Gerlich WH, Chudy M, Schaefer S, Thomssen R: Quantitative detection of hepatitis B virus DNA in two international reference plasma preparations. Eurohep Pathobiology Group. J Clin Microbiol 1999, 37:68-73.

9. Chevaliez S, Bouvier-Alias M, Laperche S, Hezode C, Pawlotsky JM: Performance of version 2.0 of the Cobas AmpliPrep/Cobas TaqMan realtime PCR assay for hepatitis B virus DNA quantification. J Clin Microbiol 2010, 48:3641-3647.

10. Mackay IM, Arden KE, Nitsche A: Real-time PCR in virology. Nucleic Acids Res 2002, 30:1292-1305

11. Allice T, Cerutti F, Pittaluga F, Varetto S, Gabella S, Marzano A, Franchello A, Colucci G, Ghisetti V: COBAS AmpliPrep-COBAS TaqMan hepatitis B virus (HBV) test: a novel automated real-time PCR assay for quantification of HBV DNA in plasma. J Clin Microbiol 2007, 45:828-834

12. Ciotti M, Marcuccilli F, Guenci T, Prignano MG, Perno CF: Evaluation of the Abbott RealTime HBV DNA assay and comparison to the Cobas AmpliPrep/Cobas TaqMan 48 assay in monitoring patients with chronic cases of hepatitis B. J Clin Microbiol 2008, 46:1517-1519.

13. Aprili G, Gandini G, Piccoli P, Bressan F, De Gironcoli M, Mazzi R, Parisi SG, Gessoni G, Marchiori G, Franchini M: Detection of an early HIV-1 infection by HIV RNA testing in an Italian blood donor during the preseroconversion window period. Transfusion 2003, 43:848-852.

14. Assal A, Barlet V, Deschaseaux M, Dupont I, Gallian P, Guitton C, Morel P, van Drimmelen H, David B, Lelie N, De Micco P: Sensitivity of two hepatitis $B$ virus, hepatitis $C$ virus $(\mathrm{HCV})$, and human immunodeficiency virus (HIV) nucleic acid test systems relative to hepatitis $B$ surface antigen, anti-HCV, anti-HIV, and p24/anti-HIV combination assays in seroconversion panels. Transfusion 2009, 49:301-310.

15. Echevarria JM, Avellon A: Hepatitis B virus genetic diversity. J Med Virol 2006, 78(Suppl 1):S36-42

16. Girones $\mathrm{R}$, Miller RH: Mutation rate of the hepadnavirus genome. Virology 1989, 170:595-597.

17. Shibayama T, Masuda G, Ajisawa A, Hiruma K, Tsuda F, Nishizawa T, Takahashi M, Okamoto $H$ : Characterization of seven genotypes ( $A$ to $E, G$ and $H$ ) of hepatitis $B$ virus recovered from Japanese patients infected with human immunodeficiency virus type 1. J Med Virol 2005, 76:24-32.

18. Lindh M, Hannoun C, Malmstrom S, Lindberg J, Norkrans G: Lamivudine resistance of hepatitis $B$ virus masked by coemergence of mutations in probe region of the COBAS AMPLICOR assay. J Clin Microbiol 2006, 44:2587-2589.

19. Jang SY, Kim MS, Park MS, Lee KM, Chung HW, Chun J, Lee CH: Designing primers from multiple sequences using Matchup program to improve detection of hepatitis $B$ virus by polymerase chain reaction. J Microbiol 48:111-116.

20. Pawlotsky JM: Molecular diagnosis of viral hepatitis. Gastroenterology 2002, 122:1554-1568

21. Meng S, Li J: A novel duplex real-time reverse transcriptase-polymerase chain reaction assay for the detection of hepatitis $C$ viral RNA with armored RNA as internal control. Virol J 2010, 7:117.

22. Huang J, Yang CM, Wang LN, Meng S, Deng W, Li JM: A novel real-time multiplex reverse transcriptase-polymerase chain reaction for the detection of HIV-1 RNA by using dual-specific armored RNA as internal control. Intervirology 2008, 51:42-49.

23. Meng S, Zhan S, Li J: Nuclease-resistant double-stranded DNA controls or standards for hepatitis B virus nucleic acid amplification assays. Virol J 2009, 6:226.

24. Walkerpeach CR, Pasloske BL: DNA bacteriophage as controls for clinical viral testing. Clin Chem 2004, 50:1970-1971.

25. Stocher M, Berg J: Internal control DNA for PCR assays introduced into lambda phage particles exhibits nuclease resistance. Clin Chem 2004, 50:2163-2166.
26. Proudnikov D, Yuferov V, Zhou Y, LaForge KS, Ho A, Kreek MJ: Optimizing primer-probe design for fluorescent PCR. J Neurosci Methods 2003, 123:31-45

27. Vermehren J, Kau A, Gartner BC, Gobel R, Zeuzem S, Sarrazin C: Differences between two real-time PCR-based hepatitis $C$ virus (HCV) assays (RealTime HCV and Cobas AmpliPrep/Cobas TaqMan) and one signal amplification assay (Versant HCV RNA 3.0) for RNA detection and quantification. J Clin Microbiol 2008, 46:3880-3891.

28. Chevaliez S, Bouvier-Alias M, Pawlotsky JM: Performance of the Abbott real-time PCR assay using m2000sp and m2000rt for hepatitis $C$ virus RNA quantification. J Clin Microbiol 2009, 47:1726-1732.

doi:10.1186/1743-422X-8-227

Cite this article as: Sun et al:: Development of a new duplex real-time polymerase chain reaction assay for hepatitis B viral DNA detection. Virology Journal 2011 8:227.

\section{Submit your next manuscript to BioMed Central and take full advantage of:}

- Convenient online submission

- Thorough peer review

- No space constraints or color figure charges

- Immediate publication on acceptance

- Inclusion in PubMed, CAS, Scopus and Google Scholar

- Research which is freely available for redistribution

Submit your manuscript at www.biomedcentral.com/submit
C) Biomed Central 